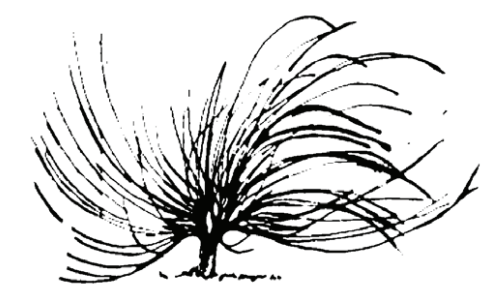

\title{
Affective filter influence on students' initiating the b.a.englishmajor at the Universidad Nacional, Chorotega branch in Nicoya, Guanacaste, Costa Rica
}

\author{
Yendry Dover ${ }^{1}$ \\ Universidad Nacional, Costa Rica \\ Heredia, Costa Rica \\ yendrydover@gmail.com
}

\begin{abstract}
Affective filter a commonly accepted component in foreign language learning for adults, are internalized emotional barriers frequently established by learners as a way of psychologically protecting them when confronting the challenge of producing the target language Krashen (1987). While this natural defense mechanism is attempting to help the individuals from damaging their egos, it is in fact counter-productive to the language learning process. This qualitative study explores and describes the negative impact of affective filters in a group of entrance-level, young adult students at the Universidad Nacional, Chorotega Branch campus in Guanacaste, Costa Rica. In addition, it tests some strategies in lowering the affective filter in this particular group. The results showed that there was a significant impact in how affective filter delimit the learning process and the need for professionals in the field of language learning to address this issue especially in the beginning of the language acquisition process.
\end{abstract}

Recibido: 23 de agosto de 2011 - Aprobado: 01 de octubre de 2012

1 Máster en Educación con Énfasis en la Enseñanza del Inglés de la Universidad Nacional, Costa Rica y Bachiller en la Enseñanza del Inglés. Asistente académica y profesora de inglés en la Universidad Nacional, Costa Rica. 
Keywords: language acquisition process, young adult learners, affective filter.

\section{Resumen}

Los filtros afectivos son uno de los componentes del aprendizaje de un segundo idioma en adultos; constituyen barreras emocionales frecuentemente establecidas por los aprendices como una forma de protegerse psicológicamente cuando se ven afectados en el momento de confrontar la producción en el idioma meta. Mientras este mecanismo de defensa personal trata de ayudar para no dañar el ego de los individuos, es de hecho contra producente en el proceso de aprendizaje. Este estudio cualitativo explora y describe el impacto negativo del filtro afectivo en adultos jóvenes del primer nivel del diplomado en inglés de la Universidad Nacional Campus Nicoya. Además, menciona algunas estrategias para bajar los filtros afectivos de este grupo. Los resultados muestran que hubo un significante impacto acerca como los filtros afectivos limitan el proceso de aprendizaje y la necesidad de los profesionales en el área de enseñanza de idiomas por direccionarse en este tema principalmente en el inicio del proceso de adquisición de un segundo idioma.

Palabras clave: proceso de adquisición de un segundo idioma, estudiantes adultos jóvenes, filtro afectivo

\section{Introduction}

I $\mathrm{n}$ response to globalization as a catalysis for elevating English as the "universal language" in trade, tourism, political and international relations, one of the most pronounced changes in the forefront of educational curriculum development has been the introduction and development of English as a Foreign Language (EFL) in the majority of countries which do not have this language as their native tongue. Compared to English as a Second Language (ESL), it frequently implies learning the language in-situ of the learner's native environment. Costa Rica is one of the countries which has gone to great economic and academic strides to compete in a foreign market by intensifying EFL programs in elementary, secondary and superior education. Research concentrating on EFL, particular to the country is 
Affective filter influence on students' initiating the

essential to further progress in the long term goals of competing in foreign markets and improving national service sectors aimed at foreigners whose native or second language is English.

The emergence of EFL curriculum development in many countries like Costa Rica is particularly difficult because it is being applied within all age groups within the country. In other words, adults are required to learn the language to compete in the labor markets of tourism, international trade and political arenas. At the same time, intense programs are being carried out in primary and secondary schools, while new majors are being opened and students are being trained to be future professionals fully proficient in the language. The field of EFL is too broad to be addressed in any one single research project, and for this reason the focus of this research is specifically to address the affective filter process in adult college-entrance level students.

On a natural level as first language, language development occurs simultaneously with physiological, psychological and sociological development. Numerous studies have been done to show how first language is intrinsically integrated into stages of overall development of an individual. Acquiring a foreign language for adults, however, is very different because they already have their native language with which to communicate and have already matured physically, psychologically and socially. That is to say that this process, which is inherently dependent on these other faucets of an individual development, must take place in another manner which is generally considered to be artificial and emotionally challenging. For this reason, affective filter is much more pronounced in adult foreign language learning then they are for native language learning or even for foreign language learning for children.

This qualitative research project proposes to address the problem of affective filter delimiting the interaction of the target language in speaking and listening tasks carried out in the college classroom. It takes an in-depth look at one group of adult learners in 4 college courses and describes the intensity of affective filter and how it interplay with the language development of the subjects. By doing so, it indicates the significance of addressing affective filter in beginning level adult learning college English courses. In addition, it examines four strategies for lowering the intensity of affective filter and determines the level of success of these strategies for the target population under study. Before examining the methodology, results and discussion, as well as 
the conclusions of the study, a brief theoretical explanation of affective filter and adult foreign language learning provides background information valuable to the understanding of the topic.

\section{Young adult learning}

The participants of the study are 8 students: 6 women and 2 men among the ages of 18 and 27. Only one of the participants has family responsibility and the others are just students who live with their parents near Nicoya city. The previous information locates students between the young adult periods of life which present some important characteristics that are well recognize among this people. Lara, Martínez, Pandolfi and others (2006) define this period as a stage that starts at the age of 20 and ends around age 40 .

The main characteristic of this period of life is related to the process of assuming social and family responsibilities, it means that people are going to be more responsible with their personal and educative life. The social roles they have to develop in this phase are essential in the development of the learning process, because they have the capacity to adapt themselves to new situations and relate them to the learning process of a second language, which facilitates the assimilation of new information and contents.

Stevens-Long (1979) says that young adult learning is defined as adaptation, since students have probably suffered some loss, frustration or failure in diverse ways and from this experience they start to create their adult life. Also for this author this is the right time for the learning process; adult learners want to be the owners of their education and they will resist the activities that interfere negatively in their competence. It is well-known that they need direct and tangible experiences in which they apply English language in real context. As well, they need to receive feedback about what they are doing and the results of their efforts. The previous experiences young adult learners have will permit an easier adaptation during the acquisition of the new language. Besides, they are better willing to participate in small-group activities which will move them beyond understanding the target language.

Adults not only collect information and knowledge created by outsiders (family, classmates, friends and professors), but also examine their own reality and make their own learning based on the environment 
that could provide effective adult learning due to the continuous interaction. Although the constant interaction of young adults in the new language creates new settings for acquisition, some of the emerging problems are producing interference during learning.

Adult learners often start different English courses but for many reasons they fail it, then they start another one and face some difficulties and fail again. This can happen for several reasons, but the most important one is that English programs are divided according to the skills and their emphasis area. Frequently, no matter how professors try to teach, some problems will emerge which block learning and acquisition. This is why it's important to know about the affective filter hypothesis and how it can affect students' learning.

\section{Affective Filter Hypothesis}

Krashen (1981) says that the concept of affective filter was proposed by Dulay and Burt (1977), and it is consistent with the theoretical work done in the area of affective variables and second language acquisition. Then, he confirmed that a variety of affective variables related to success in second language acquisition can be placed into one of these three categories: Motivation. Performers with high motivation generally do better in second language acquisition (usually, but not always, "integrative" 13). (2) Self-confidence. Performers with self-confidence and a good self-image tend to do better in second language acquisition. (3) Anxiety. Low anxiety appears to be conducive to second language acquisition, whether measured as personal or classroom anxiety. This hypothesis describes the influence of some affective factors interfering during adult second language learning.

Krashen (1987) focuses his hypothesis in the relationship that exists between affective variables and the process of second language acquisition, and consequently to the strength or level of the student/ learner's Affective Filter. When students are highly motivated and with a lot of confidence during the learning process, acquisition is going to be easy. Similarly, if their level of anxiety is low, this is going to allow them to interact with the new language in a better way.

Also there are more definitions of "affective filter." Rossiter (2003) cites Krashen (1981) who refers to affective filter hypothesis as the existence of an internal barrier that interfered with second language 
acquisition when learners were anxious or bored. According to Yule, the term affective filter is often used to describe a kind of barrier to acquisition that results from negative feelings or experiences; basically, if the person is stressed, uncomfortable, self-conscious or unmotivated it is unlikely to learn anything.

Also, Dulay (1982) uses the term "filter" to refer to an affective factor that screens out certain parts of learners' language environment. The filter is the part of the internal processing system that subconsciously screens incoming language based on what psychologists call affect, motives, needs, attitudes and emotional states.

Among all the aspects in which affective filter focus, the main factors are motivation, anxiety and self-confidence. Such factors influence students' learning in a negative way, and don't allow them to defeat the fear they feel when they have to communicate in the target language, this blocks the normal interaction and delimits the acquisition. As some people say, a lack of confidence causes low levels of motivation, and high levels of anxiety cause more difficulties, regardless of what activities are practiced.

According to Dulay (1982) low anxiety levels tend to be more closely related to good scores on speech tests than to grades. This is associated with people's personality depending on the reaction to some learning situations such as taking an exam, speaking in front of the class or doing an oral presentation, which can provoke difficulties on the production of the new language. On the other hand, high levels of anxiety are very frequent in second language learners, people get worried because they want to speak accurately and express all the ideas they have in an appropriate form. However, this is not possible due to the differences that exist between their native language, and English, their second language.

Most of the time people present some general symptoms of anxiety which can include fear, worry, and hyperventilation, excessive sweating, blushing and in some cases increased blood pressure and muscle tension. These elements are present in almost everybody at some point in their lives, but primarily if they are involved in new circumstances that create changes in their behaviors and life. Equivalently the term anxiety is defined in the Cambridge Learner's Dictionary as the feeling of being really worried. 
These behaviors were the first signs identified in students who are part of the study. They are the reason of interest of this research in order to identify if the influence of affective filter hypothesis is affecting them negatively and causing more troubles during the learning process of English as a second language.

Norris-Holt (2001) defines motivation as learner's orientation in regard to the goal of second language learning. Motivation is divided into two basic types: integrative and instrumental. Integrative motivation is characterized by the learner's positive attitudes towards the target language group and the desire to integrate into the target language community. On the other hand, instrumental motivation motivates the goal to gain some social or economic reward through L2 achievement, thus referring to a more functional motivation for language learning. Both forms of motivation are examined in light of research which has been undertaken to establish the correlation between the form of motivation and successful second language acquisition.

Correspondingly, personality factors are part of people's behavior due to the influence of those in their life. The last element of this hypothesis is self-esteem or self-confidence, which is one of the factors Krashen defines as the condition when learners have a good self-image about themselves and with a positive anxious temperament which make available in second language acquisition.

Some researchers try to define the term, Manson (2002) defines self-confidence as a provision of anxious temperament, and this appears to be related to children and closely linked to the image itself. In the English learning process there are several situations that challenge students' personality; if they have confidence to do new things they will be able to do it and will do well everything they try. But if not, all the process is going to be limited, not being able to move forward.

Referring to this term, Coopersmith (1967 cites in Yang, 2005) who says self-esteem is "a personal judgment of worthiness that is expressed in attitudes that the individual holds towards himself, and indicates the extent to which the individual believes in himself to be capable, significant and worthy. The condition cited before by the different authors about self-confidence emphasizes the necessity of students to believe in themselves and how this attitude will help them during the acquisition of a second language. 
Also, according to Schutz (2007), low motivation, low self-esteem, and debilitating anxiety can combine the raise of the affective filter and form a mental block that prevents comprehensible input from being used for acquisition. In other words, when the filter is up it impedes language acquisition. On the other hand, a positive effect is necessary but not sufficient on its own for acquisition to take place. This quotation exactly reflects the problem of this study, because students that are part of the process are facing these characteristics, but they do not realize the influence of those in their learning and acquisition process; they just know that sometimes they feel nervous during an oral presentation. For example if they are speaking and forget the word in English that explains their idea and they stop talking, they do not recognize that these kinds of situations are common in their classroom tasks.

With the purpose of finding the answers to this and other questions in the second language learning and acquisition process, it is necessary to consider students' environment and reality. Also, it is essential to know their feelings about different situations that interfere during the learning process and how they affect them. Second language research is very common; however, this in particular is closely related to the aim of qualitative research because the purpose of this is to be close to the people participating in the research, and the techniques used during the data collection allow to stay in contact with students and interpret the different reactions they have in a better way.

\section{Qualitative research}

With the aim of determining if there is negative influence of affective filter hypothesis in advanced English students at U.N.A., Nicoya campus, it is necessary to use appropriate research methodology and techniques. A qualitative approach allows access to those possibilities because it gives the researcher the opportunity to be in contact with students and interact with them during all the investigation.

Hernandez, Fernandez and Batista (2007) describe qualitative approach as an inductive process (explore and describe, and then generate theoretical perspectives) because it gives the possibility to go to the classroom to explore and find out the reality in which students live and this generated a different perspective about their environment and how to understand it. This allows a better way to describe the environments 
in which you want to develop the study. This is exactly what authors above referred to; because, only a qualitative approach allows this kind of exploration and description. At the same time this approach is oriented to study in depth the complex social reality, since in the process of data collection the researcher accumulates many texts from different techniques. (Osses, 2000). This in-depth study allows the investigator to have a clearer concept of the social reality of the research topic and how it influences, mediates or affects the target population.

\section{Observation}

The process of collecting qualitative data is extremely relevant to the investigation; this data is the real perspective of the learners' participation in the study. Regarding qualitative observation, Hernández, Fernández and Batista (2006) state that qualitative observation is not just a mere contemplation (sit and watch the world and take notes) It involves deep digging into social situations and maintaining an active and constant reflection, as well as being attentive to details, situations, events and interactions. This technique requires the researcher to be completely involved in the topic and to keep an active position; at the same time, it lets a permanent reflection about student's role and the purpose of observation of the problem.

The way qualitative observation acts makes the investigation more interesting at every moment because every single reaction requires the researcher to be more precise in the identification of affective filter factors in students and the different reactions they have at the moment and how they are affecting them.

The observation was performed to the group at different moments and classes; all this was in order to know if there is a link between the moments and actions, and mainly if there are differences between the participants. It is important to mention that the 8 students present different factors at different moments. However, in the analysis the link between them was obvious, because all the students reacted in the same way to some situations regardless of the moment.

The most relevant of this technique was how the data collected helped create, develop and write the appropriate questions for the deep interviews, where the main idea is to be accurate to the research objectives and students' realities, all this due to the interpretation of students' 
performance. Although the questions were the same for all of them the emphasis and depth of the interview can be varied among the participants.

\section{In-depth interview}

The second used technique is in-depth interview, after the lengthy observation of the group and the basing of some ideas on that, the next step is to interview just some of the students that present some characteristics of affective filter influence; in order to come up with a truthful research, deep interview is the most accurate technique, because this is more reflexive, open and personal. The best thing about this technique is its format, which allows a close meeting with some students and the interaction with them using some specific questions previously selected for such students.

In regard to this topic, Hernandez and others (2006) state that in a qualitative interview questions can be asked about experiences, opinions, values and beliefs, emotions, feelings, facts of life, perceptions, attributions, etc. This investigation conducts interviews based on previous conditions identified in the observation, the deep interviews allow for a close interaction between the researcher and the student. It also provides a good environment for a free talk and the opportunity to get deep in the searching of information for the study, through this technique some evidence of affective filter factors emerges, some of it is of big influence for the elaboration of the focal group which really helps the investigation.

With the execution of this technique it was extremely necessary to look for a good environment and create the right atmosphere in order to generate a close interaction between the researcher and the student. The aim of the technique was to ask indirect questions to students trying to guide them to the real information that the researcher wants to know without forcing the answers. The idea was to try to find out how they feel during some class activities in which they face troubles, mainly if they act improperly or forget their speech and what are the causes of that.

\section{Focal group}

The focus group is a qualitative technique for collecting data and information, obtained through semi-structured interviews and leading to a homogenous group. For its implementation, it is essential to know students in advance and use pre-designed guides based on the theory and the 
elements being studied, as well as personality information about the students that are going to be part of the group. Additionally, it is recommended in some cases, to use different resources to facilitate the compilation of information such as socio-dramas, stories of experiences, pictures and images, etc.). Likewise, it is necessary to use equipment such as a recorder, video recorder, camera and others, which will facilitate the analysis of information collected during the application of the technique.

Hernandez refers to focus group technique as a kind of group interview, which consists of small group meetings in which participants talk about one or more issues under the guidance of a specialist (Hernandez and others 2006). This relationship promotes a more pleasant atmosphere among the participants of the group and they can set a common topic of conversation, or one that is important for everyone. Students during speaking activity in groups are able to analyze more and remember issues that for whatever reason had been forgotten or not expressed during the deep interview. All of this creates a greater willingness to talk and think.

Also it should be emphasized that the focus group technique is a popular technique for gathering qualitative data;

\section{Affective filter factors influence results}

The participants of this study are at the beginning of English major, they have been affected by all sort of situations that can block this process, which are mainly affective. In this sense Dulay and Others (1982) state that these are the main obstacles when learning and acquiring a second language. Additionally, Yule (1996) reports affective filter as barriers encountered by students during language acquisition.

Once the research puts all the techniques into practice, it is important to determine if the collected data reflects the influence of the affective filter factors hypothesis and whether or not it has an effect on the learner's acquisition; also, taking into account, as reference, possible student's experience with a second language during the young-adult age period.

This section also shows the diagnosis of the students' reality and perceived needs of students participating in the research, in order to build with them some affective filter management strategies that will cover those needs. In this sense, it inquires into which affective filter are present or not in students. Also, it brings together the explanations 
that students give to the presence of such filter and additionally, it investigates the experiences and personal learning knowledge of students in the first level of the English major.

During the observation students show some reactions that according to the theoretical framework are evidence of affective filters. These reactions include fear, nervousness, involuntary movements on legs and hands, shaking and quivering. They act without realizing what they are doing or saying; mainly during some learning activities that force them to interact in the new language, those effects were common issues during oral presentations, impromptu speeches or when they had to give the answer to some direct questions. The influence of affective filter factor anxiety was notorious. In summary all the students show negative influence of anxiety because they present the same characteristics in different moments; mainly when they face-to-face questions, that is not an easy situation for them, but it is something they should do and confront and do their best at.

Linked to the Anxiety factor students state that during an oral presentation they feel nervous and most of the time forgets what to say, and get scared if the classmates or professor ask them questions. Moreover, they say that during the moment they were distracted and the professor asks them something, they do not know how to respond and perhaps they know it but do not say anything because anxiety affects them. Also, they say that when they are afraid their feet shake and they feel butterflies in their stomach. These conditions expressed above were present in all the students, indicating the big influence of anxiety in them.

The researcher basically considers that the students involved in this study have been influenced by the negative anxiety factor of affective filter but they do not know the implications in their English learning process. On the other hand, this phenomenon involves a complex array of issues and problems and takes place in a specific situation, in a social context and specific language. The center of this fact is how the knowledge of this problem could help learners to improve the acquisition process and at the same time be aware of the elements that provoke the troubles, as well as management of appropriate strategies in order to diminish affective filter factors.

Likewise, other factors emerge through the research such as fear, phobia, nervousness and stress. Those were common in situations where students perceive threat or danger which is concerned about something 
new during the learning process. Six of the students express that they notice nervousness on them when during the class the professor asks directs questions and they have to give the answer as soon as possible. At the same time fear appears during oral presentations and they get stressed out when they have to present a topic in the target language but which is difficult for them to understand it either in the mother tongue.

Based on the data collected throughout the all techniques students perceive those feelings most of the time they have to perform in the new language. Also students demonstrate negative influence of anxiety when during a presentation they used to use $\boldsymbol{u h}, \boldsymbol{w e l l}, \mathbf{m m m}, \boldsymbol{e h}, \boldsymbol{a h}$; all of them say that they were well prepared for the performance but they have forgotten everything once they were in front of the class. Those utterances were noticed during the observation, in the interview and focal group, this proved that students act similarly throughout learning situations they face.

Also, with the techniques applied it is possible to determine if motivation factor is present or not on students. Related to that, low levels of motivation were evident according to the different moments observed. Two students did not want to participate in the activities the professor assigned, the same students during the focal group expressed that sometimes they do not like the activates prepared by the teacher; however they have to be part of those because of the grade, but they are not motivated to perform them.

The other six students were neither interested in the class nor in the performance of some activities, but they increase their motivation if the topic is familiar to them or if this was a very easy topic where they can express a lot or easy to talk about. For them, motivational activities are those were they can participate in interviews with foreigners or out of the university in real life conversations.

The previous statements denote students' differences in the level of motivation. This means that just two of them demonstrate low levels of motivation, but they express that what motives them is the necessity to finish the career and find a good job. The other six students also have the same motivation but at the same time they want to achieve their goals in the university and they are interested in learning everything about the language.

It is important to be familiar with the idea that students' age and personal circumstances at the university level will provide a great 
number of responsibilities; for that reason, motivation drives them to continue with their studies. The idea of having a better social condition motivates students to overcome the problems that appear in the learning process. Also, motivation promotes significant learning, which allows them to continue learning English, students consider that the learning they have is good and the interaction with foreigners is a plus to the learning and acquisition process.

Regarding to self-confidence factor, throughout the observation it was perceived that students feel uncomfortable talking in front of the class, but if they interact in small groups or with their close friends the performance improves and they express their ideas in English quite easily.

The development of self-confidence for students is not easy; however, with time and interaction between them, their level of comfort increases and that brings them closer together. For the learning process, to develop trust may allow more spaces for interaction between them and their behavior

The support among them appears after the participation in different activities. At the same time, as far as self-confidence emerges, students show a highest level of this factor. In the focal group all of them say that they felt uncomfortable if a classmate corrects them or asks direct questions, they did not like to talk because they felt that the partner was laughing at them. They explain the effects of low self-confidence on them and this proof the negative influence of this factor on the learning process.

Also, all of them give different examples about when they feel more confident in class. Some of these examples are related to the idea of moving any part of their body during a presentation, others say that laughter gives them more confidence and helps them not to be afraid. In addition, previous knowledge about some topics also influence in a higher level of confidence.

Since confidence is the most important thing to conquer fears, it appears through the process of learning a new language and going beyond their expectations. According to Krashen (1981) people with self-confidence have a good image and tend to be better at acquiring a second language. It is essential to mention that in this category not all the participants made statements about it. From those who gave their opinion the majority show that the lack of confidence in them is merely to express themselves easily. 
Affective filter influence on students' initiating the

Based on the different results obtained through the techniques it was necessary to think about to the possible solution for the problems that emerged in second language learning at the first level of English. The idea of creating a group of strategies to help students with the management of those affective filter factors which influence them negatively was proposed by some students in different moments of the research.

\section{Strategies for affective filter management}

This proposal is the result of the process experienced by the participants and the researcher of this study. It is based on the experience, commitment, reflection and active participation of each actor. Educational strategies detailed below are tools to support students during their learning process; also, they can be useful to defeat the affective filters in both learning and acquisition of English. The objective of this proposal is to achieve lower levels of anxiety in students with negative affective filter, and at the same time to increase motivation and confidence and to empower students to be concerned about seeking appropriate and relevant strategies in order to find a solution to their learning and acquisition problems.

In the framework in which this graduation project takes place, it is important to look for the way the researcher and participants raise awareness of the identification of needs and problems on students during learning and acquisition of the English language, simultaneously finding explanations for questions they have about their difficulties and then determine appropriate and feasible solutions to put into practice.

These strategies are created and implemented both by students and researchers during the English as a second language class, where educational, personal, motivational and contextual factors are evident in the study. The strategies in which this project builds on were proposed by Oxford (1990) who suggests that strategies are steps or procedures taken by students to facilitate the acquisition of skills or knowledge, and to enhance their own learning of a new language. Similarly O'Malley (1990) defines "strategies such as special thoughts or behaviors that individuals use to help, learn or retain new information." These strategies are conceptualized as tools that help students to monitor and be aware of their learning process. It begins when people learn a new language and don't have appropriate behaviors, which are caused by factors that 
affect performance in the language. Therefore, it is necessary to begin an assessment of students' needs.

In this study conducted with English major students at the University, Nicoya campus, who are influenced by affective factors, it was necessary to find activities to help them obtain ways to confront high anxiety, low motivation and low self-confidence. Once students determine the ways negative affective filter affect them, and they agree to the design of specific activities related to each factor, the elaboration of the solutions starts.

The strategies are The mask, Comfortable chair, Top Banana and The expert. By mutual agreement between the people involved in this process only three of them were used. These strategies were developed to compensate a deficient thinking in nursing students. Each strategy is based on reducing the negative influence of a specific affective filter factor found in students.

\section{The mask}

This strategy intends to use English in the best way without trait anxiety and gives confidence in learning situations such as prepared or spontaneous presentations. Similarly it's intended to be used during, or after the presentation of the subject, when people ask questions to the group. The idea is that a mask hides their face, helping them not to be nervous, worried or doubtful.

Students are going to wear the mask in order to hide their fears of been in front of the class. This strategy was used for the participants of the research and all of them express that during the presentation they wear the mask they felt more relax, they were not worried because if they were a little lost during the presentation their classmates could not notice them worried because they could not see their face. The performance of the topic was more fluent and accurate.

\section{Comfortable chair}

The primary objective of this strategy is to control nervousness on students during a presentation. As it was the case with the previous strategy, this one tries to keep students' anxiety low during a presentation. With this activity students should feel relaxed during their 
presentation and not show their nervousness if they ever move any part of the body and start walking from side to side. The idea of this strategy is that students know they can dominate or control anxiety and the important thing is that there is a possibility to find ways to reduce the factor.

The strategy consists on giving the speech or presentation seated on a chair, they have to focus students' attention on them but at the same time they have to be relaxed; this was proposed because students express the necessity to move during the presentation in order to feel less nervous, but if they are seated it is not necessary to do that, which at the end helps to the concentration during the activity.

\section{Top Banana}

This strategy is to motivate students to do their best in the process of acquiring a new language. The idea is that the teacher motivates students whenever they evidence progress in their learning. This is a kind of reward students can obtain if the presentation they are having during the activities is good and if it is improving each class.

This will help students to be recognized by the rest of their classmates and professors, the idea is to explain the objective to the students of this strategy at the beginning of the course and tell that each month one student is going to receive the award in a short ceremony among the classmates, professor of the course and coordinator of the career. That will keep them motivated and with a goal of getting it as many times as possible, and this will improve their earning and acquisition process, as well.

\section{The expert}

This strategy is used to ensure that students gain more confidence and increase their motivation to cope with their fears when they have to communicate in English. This is a little different from the other strategies and cannot say that it is noticeable.

The main idea of this strategy is to empower students so that they feel qualified to speak on any topic, to feel able to talk about issues not common to them. This relates to how to develop a high self-confidence as an opportunity to perform better, knowing they have the ability 
and capacity to talk about everything that comes up during the learning process.

Each of these strategies should be guided by the teachers of the course, since they are the ones who know each student and must identify their weaknesses. The main idea of the strategies is that the student has extra support for effective communication in the target language.

Besides, it is important to involve learners in this process of improvement because they need to know and cognize that learning a second language can have some troubles but at the same time that are different ways to overcome them.

\section{Conclusion}

Once the research is finished, it is essential to mention that affective filter factors are present in our first level English major students. Also, that these factors are affecting them and becoming problems that can stick with them if they don't use appropriate strategies to help overcome them when they start showing up.

Also, students are more influenced by the anxiety factor and this is blocking the improvement in different areas, this is part of all of them in the different moments of the learning process. This factor is represented through the fear, nervousness and worry in learning activities such as oral presentations, impromptu speech and direct questions. And this is happening because they do not trust in themselves, their classmates and professors.

Regarding self-confidence, they express that don't feel comfortable while expressing in English and does not help students to put into practice what they already know in English. The level of this factor varies depending on the moment of the class and classmates' behavior.

Also, according to the research, students are motivated but this is not enough in most of them. Motivation is low and most of the time this is more related to the rewards they are going to obtain once they finish the career. In some cases it is associated with the learning of the English language and the good performance they can have in the learning process.

At the end of the research was evident that the influence of those affective factors is negative because the levels of the factors are against students; according to the data the level of anxiety is high, motivation is 
low and students almost do not have confidence; that gives a clear idea that the purpose of the research was right and appropriate, because the objective of creating some strategies that to help students was done properly with the help of the same students who participated in the project.

\section{Recommendations}

Due to all of these conclusions and for a good management of affective filter factors, it is recommended try to control the negative influence of these prior to some of the learning situations described above. In addition, they constantly enhance confidence in students despite the problems they confront, in this way students are not going to be affected by new situations in the learning process. Therefore, there's the necessity to express what they have or feel no matter if it is personal or academic. Moreover, they try to create awareness in students during the learning processes in order to help them resolve negative influence of factors through their own experience.

Base on all the data collected during the research it is going to be possible to establish identification criteria of students in order to recognize if they are influence by affective filter factors. Those will help professors to identify and understand students' behavior and attitudes in the performance of English activities

The objective is that students learn to manage affective filter factors so they do not affect negatively the process of learning a second language. At the same time students can organize themselves and work together on each of the circumstances they face to elaborate strategies that will help them.

Besides, it is necessary to make a recommendation to the educational institution, to advise their teachers to generate spaces where students can say what affects their learning. Consequently, it is recommended that the professors determine if the affective filter factors affect all students in the first level of the major English class, and if it happens both in the Nicoya and Liberia campus. This would be of great benefit to students from both campuses, as long as they apply or replicate this study using the methodology and techniques in order to generate more strategies and activities for students.

It would be of great importance to encourage teachers and the University to implement this type of research and educational experiences, 
in order to benefit students during their learning and acquisition process of English. This would help the Chorotega Branch at Universidad National to become an entity specialized in working with affective filter factors in the country. And at the same time, involving students in these processes and making a meaningful experience for compelling activities generate elements that solve the negative influence of factors which can damage the learning process.

\section{References}

Dulay, H. et al. (1982). Language two. Nueva York: Oxford University Press.

Krashen, S. (1981).Second language acquisition and second language learning. Oxford: Pergamon Press.

Krashen, S. (1987). Principles and practice in second language acquisition. Englewood Cliffs, New Jersey: Prentice-Hall International.

Hernandez, S., at al. (2006).Metodología de la investigación. Mexico: McGraw-Hill.

Lara, E. et al. (2006). "El adulto joven". Recuperado el 17 de abril del 2008. disponible en http://www.avizora.com/publicaciones/psicologia/textos/adulto_joven $0015 . h t m$

Manson, T. (2002). "Affective filter". Recuperado el 15 de setiembre de 2009, de http:// www.timothyjpmason.com/WebPages/LangTeach/Licence/CM/OldLectures/ L11_Affective_Filter.htm

Norris-Holt, J (2007) "Motivation as a Contributing Factor in Second Language Acquisition". The Internet TESL Journal, 7, (6).

Osses, S. et al (2000). "Investigación cualitativa en educación: hacia la generación de teoría a través del proceso analítico". Recuperado el 27 de octubre de 2008. Disponible en http://www.scielo.cl/scielo.php?script=sci_arttext\&pi$\mathrm{d}=\mathrm{S} 0718-07052006000100007 \& \operatorname{lng}=\mathrm{es} \& \mathrm{nrm}=\mathrm{iso} \& \operatorname{lng}=\mathrm{es}$

Oxford, R. (1990). Language leaning strategies: what every teacher should know. United States: Heinle \& Heinle Publisher

O’ Malley, J. \& Uhl, A. (1995). Learning strategies in second language adquisition. New York: Cambridge University Press.

Rossiter, M. (2003). "The effects of affective strategy training in the ESL Classroom". Teaching English as a Second or Foreign Language, 2 (7).

Stevens-Long, J. (1979). Adult life: Developmental processes. Palo Alto, California: Mayfield Publishing Company.

Yule, G. (1996). The study of language. Cambridge: Cambridge University Press.

Yang, A (2005)."How self-esteem and anxiety affect second language learners. Research paper". Recuperado el 20 de agosto de 2010. Disponible en it.snhu.edu/ EFL-537/yangyating/Research\%20Paper.doc

Schutz, R. (2007).“Stephen Krashen's Theory of Second Language Acquisition”. Recuperado el 03 de mayo del 2010. Disponible en http://www.sk.com.br/sk-krash.html 